\title{
PERTUMBUHAN Chlorella sp. PADA BEBERAPA KOMBINASI MEDIA KULTUR
}

\author{
Rimba Boroh, Magdalena Litaay², Muh. Ruslan Umar², Ambeng ${ }^{2}$ \\ 1) Stasiun Karantina Pertanian Kelas II Manokwari. Badan Karantina Pertanian. \\ Departemen Pertanian. Jl. Trikora Taman Ria, Sowi, Manokwari Sel., \\ Kabupaten Manokwari, Papua Bar. 98315, Indonesia \\ ${ }^{2)}$ Departemen Biologi, Fakultas MIPA, Universitas Hasanuddin, Jl. Perintis Km 10. \\ Makassar, 90245, Indonesia \\ *e-mail: mlitaay@fmipa.unhas.ac.id
}

\begin{abstract}
ABSTRAK
Penelitian tentang pengaruh beberapa perlakuan kombinasi antara media kultur organik berupa vermikompos cair dan media kultur anorganik berupa walne terhadap pertumbuhan Chlorella sp. telah dilakukan. Penelitian ini bertujuan untuk mendapatkan kombinasi media kultur yang terbaik dalam merangsang peningkatan pertumbuhan populasi Chlorella sp.. Jenis penelitian ini adalah eksperimen menggunakan desain percobaan Rancangan Acak Lengkap dengan kombinasi perlakuan faktorial $5 \times 5 \times 2$ (5 konsentrasi perlakuan Medium Walne, 5 konsentrasi perlakuan vermikompos, masing-masing 2 kali ulangan). Chlorella dikultur selama 10 hari. Data dianalisis dengan menggunakan analisis Univariate Analysis of Variance. Hasil penelitian menunjukkan bahwa penggunaan kombinasi media kultur yang berbeda tidak berpengaruh terhadap pertumbuhan Chlorella sp. dan diperoleh kepadatan rata - rata populasi tertinggi, yaitu perlakuan V4W4 pada hari ke-9 dengan jumlah kepadatan populasi $19.530 \times 10^{4} \mathrm{sel} / \mathrm{ml}$ dan nilai laju pertumbuhan sebesar $1,8 /$ hari. Hasil uji UNIANOVA menunjukkan tidak adanya pengaruh yang nyata terhadap pertumbuhan Chlorella sp.
\end{abstract}

Kata Kunci : Vermikompos. Chlorella sp., Walne, Kultur, Kombinasi.

\section{ABSTRACT}

The research about the influence of some treatment combination between vermikompos organic liquid and inorganic culture medium walne have been done. This study aims to obtain the best combination of culture media for stimulate and to increase the population of Chlorella sp. The present experimental study use Completely Randomized Design, with a $5 \times 5 \times 2$ factorial treatment combination ( 5 medium walne treatment concentration and treatment concentration vermikompos 5), in which each treatment combination two replications. The Chollera were cultured for 10 days. The data obtained were analyzed using analysis UNIANOVA. The results showed that the combined use of different culture media affect to Chlorella sp. growth and obtained the highest average population density that is V4W4 treatment on day 9 with the population density of $19.530 \times 10^{4}$ cells / ml and the rate of growth is $1.8 /$ day. The results of UNIANOVA shows no significant effect on the Chlorella sp. growth.

Keywords: Vermikompos. Chlorella sp., Walne, Culture, Combined. 


\section{PENDAHULUAN}

Ketersediaan pakan alami merupakan salah satu faktor yang berperan penting dalam mata rantai usaha budidaya udang terutama pada fase benih. Pentingnya pakan alami sebagai sumber pakan, disebabkan dari nilai nutrisinya yang relatif tinggi dan berkaitan erat dengan jumlah kalori yang dikandungnya. Mikroalga yang terdiri dari berbagai jenis fitoplankton merupakan pakan alami yang sangat penting bagi larva udang. Salah satu jenis fitoplankton yang dapat dijadikan pakan untuk larva udang dengan kandungan nutrisi yang cukup tinggi adalah Chorella sp. (Rifai, 1994). Chollera sp. telah diteliti secara intensif karena merupakan salah satu kelompok penting di bidang akuakultur (Nurachman et al., 2015) dan bahan dasar biofuel (Chen et al., 2018). Pertumbuhan Chlorella sp. dalam media kultur sangat dipengaruhi oleh ketersediaan unsur hara terutama nitrogen dan fosfat, serta beberapa faktor lingkungan kualitas air seperti salinitas, $\mathrm{pH}$, suhu, dan intensitas cahaya yang optimum.

Berdasarkan dari beberapa penelitian terlihat bahwa media kultur yang digunakan pada umumnya berasal dari media berbahan anorganik yang telah dilengkapi dengan hara makro dan mikro nutrien yang diperlukan untuk pertumbuhan populasi Chlorella sp. Salah satu unsur makro yang sangat diperlukan untuk pertumbuhan Chlorella adalah nitrogen yang biasa diperoleh dari senyawa nitrat, nitrit, protein, dan urea, serta unsur fosfat (Priyadi, dkk., 1990). Media ekstrak tauge dan campuran pupuk limbah padi Azolla sp. dan urea merupakan salah satu media kultur yang cocok digunakan untuk budidaya phytoplankton jenis Chlorophyceae seperti Chlorella sp. (Prihantini, dkk. 2005 dalam Maharsari, 2011). Banyak media kultur yang sudah dikenal, beberapa di antaranya dapat digunakan untuk kultur Chlorella sp. Media Walne, Media Guillard's f/2, Media Erdscheiber (Chilmawati dan Suminto, 2008). Pada umumnya dalam akuakultur banyak digunakan media kultur anorganik, yang tentunya mempunyai komposisi unsur hara yang berbeda - beda dengan yang lain, dan relatif berbiaya mahal. Salah satu alternatif yang dapat dilakukan dalam budidayaan Chlorella sp. adalah memanfaatkan kombinasi antar media kultur organik dan anorganik. Ketersedian Chlorella sp. sebagai pakan alami dalam pembudidayaan ikan, udang dan kerang - kerangan merupakan hal yang sangat penting, untuk itu diperlukan suatu studi tentang penggunaan kombinasi media kultur organik dan anorganik yang dapat memberikan hasil terbaik terutama dari segi kuantitas dan kualitas Chlorella sp. yang dihasilkan. Berdasarkan uraian di atas maka untuk mendapatkan kombinasi media kultur organik dan anorganik dalam merangsang pertumbuhan Chlorella sp. perlu dilakukan penelitian, yang diharapkan diperoleh kombinasi media kultur yang terbaik terhadap pertumbuhan Chlorella sp.

\section{METODE PENELITIAN}

\section{Penyiapan Kultur Chlorella sp.}

Pengambilan sampel bibit Chlorella sp. diperoleh dari stok murni yang telah dilakukan pemurnian berulang dan telah dikembangkan kultur bibit dalam skala laboratorium di Balai Budidaya Air Payau (BBAP) Takalar, di Desa Bontoloe, Kecamatan Galesong, Kabupaten Takalar, Sulawesi Selatan. Air laut sebagai media hidup Chlorella sp. didapat setelah melalui tahap sterilisasi dengan perebusan.

Sebelum perlakuan terlebih dahulu dilakukan perbanyakan sel Chlorella sp.. Sel yang diperbanyak berasal dari stok biakan murni. Kepadatan awal Chlorella sp. yang digunakan adalah $100.000 \mathrm{sel} / \mathrm{ml}$. Untuk menghitung besarnya inokulum yang dibutuhkan digunakan rumus (Fox, 1983) : 
Diketahui :

$$
\mathrm{V}_{\mathrm{r}} \quad=\mathrm{V}_{\mathrm{c}} \times \mathrm{C}_{\mathrm{f}} / \mathrm{C}_{\mathrm{c}}
$$

$\mathrm{V}_{\mathrm{r}} \quad=$ volume inokulum yang dibutuhkan $(\mathrm{ml})$

$\mathrm{V}_{\mathrm{c}} \quad=$ volume air media kultur $(1000 \mathrm{ml})$

$\mathrm{C}_{\mathrm{f}} \quad=$ kepadatan awal yang dibutuhkan $(100000 \mathrm{sel} / \mathrm{ml})$

$\mathrm{C}_{\mathrm{c}} \quad=$ kepadatan sel inokulum $(\mathrm{sel} / \mathrm{ml})$

Kultur dilakukan pada skala laboratorium. Sampel Chlorella sp. dikultur dalam toples kaca volume 1 liter dan vermikompos cair digunakan sebagai pupuknya lalu ditambahkan medium walne dengan konsentrasi yang berbeda - beda lalu dilakukan aerasi.

\section{Pengamatan dan Perhitungan Kepadatan Chlorella sp.}

Kepadatan populasi Chlorella sp. dihitung jumlah populasi sel setiap 24 jam sekali, yang dimulai dari hari pertama sampai hari kesepuluh. Jumlah sel dihitung dengan menggunakan haemocytometer yang diletakkan di bawah lensa objektif mikroskop dengan pembesaran 10 kali. Penentuan jumlah Chlorella sp. diketahui dengan cara menghitung banyaknya jumlah Chlorella sp. yang terdapat dalam 4 kotak besar yang berukuran sisi 1 milimeter pada hemasitometer, dalam perhitungan jumlah sel juga di gunakan handcounter. Kerapatan sel dalam $1 \mathrm{ml}$ sampel dihitung dengan rumus (Prihantini, 2005) :

Diketahui :

$$
k=n \times p \times 2500
$$

$\mathrm{k} \quad=$ kerapatan sel Chlorella (sel $/ \mathrm{ml})$,

$\mathrm{n} \quad=$ jumlah total sel Chlorella sp. pada keempat kotak kamar hitung,

$\mathrm{p} \quad=$ tingkat pengenceran yang digunakan.

Laju pertumbuhan (k) Chlorella sp. di hitung dengan rumus persamaan menurut Hirata, 1981, sebagai berikut :

Diketahui :

$$
k=\frac{\log \left(\frac{N t}{N o}\right)}{T t-T o} \times 3.22
$$

$\mathrm{Nt} \quad=$ kepadatan populasi pada waktu $\mathrm{t}$,

No = kepadatan populasi sel pada waktu to,

$3,22=$ nilai konstanta,

To = waktu awal

$\mathrm{Tt} \quad=$ waktu pengamatan.

\section{Desain Penelitian}

Desain percobaan yang digunakan adalah Rancangan Acak Lengkap (RAL), dengan kombinasi perlakuan $5 \times 5$ ( 5 konsentrasi perlakuan medium walne dan 5 konsentrasi perlakuan vermikompos), dengan 2 ulangan.

\section{Analisis Data}

Data penelitian yang diperoleh di tabulasi dalam bentuk tabel sesuai dengan desain penelitian, kemudian diolah dengan penggunakan software statistik SPSS ver. 17, selanjutnya hasil olah data diinterpretasi/ dianalisis untuk memaknai data-data tersebut. Analisis data penelitian digunakan analisis UNIANOVA (Univariate Analysis of Variance), dan jika ternyata terdapat perbedaan nyata antar perlakuan maka akan dilanjutkan dengan Uji Jarak Berganda Duncan (HSD). 
Rumus Model Percobaan Rancangan Acak Lengkap Faktorial

Model :

$\mathrm{i}=1,2, \ldots 5$

$$
Y_{i j}=\mu+r_{i}+\varepsilon_{i j}
$$

$\mathrm{j}=1,2, \ldots 5$

$\mathrm{k}=1,2$

$$
Y_{i j k}=\mu+\alpha_{i}+\beta_{j}+(\alpha \beta)_{i j}+\varepsilon_{i j k} \quad i=1,2
$$

$\mathrm{Y}_{\mathrm{i} j \mathrm{k}}=$ hasil pengamatan untuk faktor $\mathrm{A}$ taraf $\mathrm{ke} \mathrm{i}$, faktor $\mathrm{B}$ taraf ke- $\mathrm{j}$ dan pada ulangan ke- $\mathrm{k}$.

$\mathrm{M} \quad=$ nilai tengah umum

$\alpha_{i} \quad=$ pengaruh faktor $A$ pada taraf ke $\mathrm{i}$

$\beta_{\mathrm{j}} \quad=$ pengaruh faktor $B$ pada taraf ke $\mathrm{j}$.

$(\alpha \beta)_{i j}=$ pengaruh interaksi $A B$ pada taraf ke $\mathrm{i}$ (dari faktor $A$ ), dan taraf ke- j (dari faktor ke B)

$\varepsilon_{i j k}=$ pengaruh acak (galat percobaan) pada taraf ke $\mathrm{i}$ (faktor $\mathrm{A}$ ), taraf ke j (faktor $B$ ), interaksi $A B$ yang ke i dan ke j , dan pada ulangan ke $k$.

Rumus Uji Duncan :

Persamaan umum Uji Jarak Berganda Duncan (Gaspersz, 1991) :

Diketahui :

$$
\mathrm{S}_{\mathrm{Y}}=\left(\mathrm{s}^{2} / \mathrm{r}\right)^{1 / 2}
$$

$\begin{array}{ll}\mathrm{s}^{2} & =\text { nilai kuadrat tengah galat } \\ \mathrm{r} & =\text { jumlah ulangan }\end{array}$

HASIL dan PEMBAHASAN

Hasil uji UNIANOVA menunjukan tidak adanya perbedaan nyata antar perlakuan pada taraf uji $5 \%$, karena nilai $F_{\text {hitung }} 0,971<$ dari $F_{\text {tabel }} 2,21$, hal ini menyebabkan uji sederhana dengan Uji Jarak Berganda Duncan tidak dapat dilanjutkan. Namun demikian, berdasarkan pada Gambar 1 di bawah ini terlihat bahwa perlakuan kombinasi pupuk vermikompos dan walne tetap dapat meningkatkan pertumbuhan populasi Chlorella sp., walaupun dari hasil uji statistik menunjukkan tidak adanya perbedaan yang nyata antar perlakuan. Perbedaan pengaruh kombinasi perlakuan ditunjukkan dengan adanya pertumbuhan yang baik terhadap populasi Chlorella sp. di mana setiap perlakuan menunjukkan tingkat kepadatan populasi sel yang berbeda selama kultur 10 hari. Perlakuan kombinasi pupuk V4W4 (vermikompos $0.025 \%$ dan walne $0.002 \%$ ) memberikan pertumbuhan populasi tertinggi pada hari ke- 9 dengan jumlah kepadatan populasi $19.530 \times 104 \mathrm{sel} / \mathrm{ml}$. Pertumbuhan kepadatan populasi Chlorella sp. dapat dilihat pada Tabel 1.

\begin{tabular}{|c|c|c|c|c|c|c|c|c|c|c|c|}
\hline \multirow[t]{2}{*}{ No } & \multirow[t]{2}{*}{ Perlakuan } & \multicolumn{10}{|c|}{ Jumlah Sel Chlorella sp( $\times 10^{4}$ sel/ml) Pada hari ke - } \\
\hline & & 1 & 2 & 3 & 4 & 5 & 6 & $\overline{7}$ & 8 & 9 & 10 \\
\hline 1 & VOW0 & 10 & 130 & 212 & 564 & 538 & 578 & 461 & 342 & 508 & 330 \\
\hline 2 & V1W0 & 10 & 91 & 260 & 603 & 972 & 2020 & 4640 & 3040 & 7490 & 3790 \\
\hline 3 & V2W0 & 10 & 290 & 323 & 610 & 1499 & 2970 & 5990 & 3820 & 4760 & 5380 \\
\hline 4 & V3W0 & 10 & 91 & 205 & 428 & 1020 & 1660 & 2800 & 2660 & 4450 & 5910 \\
\hline 5 & V4W0 & 10 & 135 & 295 & 583 & 1360 & 3660 & 3250 & 3770 & 6700 & 6890 \\
\hline 6 & V0W1 & 10 & 84 & 364 & 731 & 1478 & 3110 & 9530 & 6160 & 4840 & 5840 \\
\hline 7 & V1W1 & 10 & 89 & 249 & 405 & 931 & 2280 & 3300 & 1830 & 7330 & 7360 \\
\hline
\end{tabular}

Tabel 1. Pertumbuhan populasi sel Chlorella sp. pada media vermikompos dan walne dengan konsentrasi berbeda selama penelitian 


\begin{tabular}{llllllllllll}
\hline $\mathbf{8}$ & V2W1 & 10 & 102 & 299 & 801 & 1800 & 3240 & 5440 & 6970 & 8660 & 10440 \\
$\mathbf{9}$ & V3W1 & 10 & 144 & 263 & 487 & 1490 & 2450 & 3020 & 4030 & 8510 & 10080 \\
$\mathbf{1 0}$ & V4W1 & 10 & 260 & 266 & 549 & 1480 & 2750 & 6840 & 3160 & 6180 & 7820 \\
$\mathbf{1 1}$ & V0w2 & 10 & 239 & 304 & 697 & 1011 & 2860 & 2840 & 3930 & 5600 & 6640 \\
$\mathbf{1 2}$ & V1w2 & 10 & 97 & 244 & 732 & 1162 & 3030 & 8670 & 4770 & 6370 & 9780 \\
$\mathbf{1 3}$ & V2w2 & 10 & 121 & 339 & 961 & 2140 & 4570 & 5610 & 7030 & 11490 & 14260 \\
$\mathbf{1 4}$ & V3w2 & 10 & 133 & 264 & 674 & 1350 & 3340 & 5500 & 5290 & 9310 & 1232 \\
$\mathbf{1 5}$ & V4w2 & 10 & 73 & 265 & 258 & 970 & 1790 & 3330 & 5590 & 6440 & 5800 \\
$\mathbf{1 6}$ & V0w3 & 10 & 119 & 303 & 781 & 1170 & 3070 & 6860 & 4230 & 7780 & 9540 \\
$\mathbf{1 7}$ & V1w3 & 10 & 93 & 232 & 664 & 926 & 2230 & 2880 & 8890 & 6100 & 8750 \\
$\mathbf{1 8}$ & V2w3 & 10 & 76 & 367 & 811 & 2070 & 3800 & 4230 & 5690 & 9240 & 9330 \\
$\mathbf{1 9}$ & V3w3 & 10 & 110 & 253 & 711 & 1860 & 4030 & 4840 & 5530 & 9010 & 11290 \\
$\mathbf{2 0}$ & V4w3 & 10 & 106 & 346 & 489 & 1500 & 2700 & 4210 & 5380 & 10380 & 8730 \\
$\mathbf{2 1}$ & V0w4 & 10 & 97 & 459 & 813 & 914 & 1960 & 2290 & 2820 & 7010 & 8400 \\
$\mathbf{2 2}$ & V1w4 & 10 & 86 & 205 & 672 & 1021 & 1910 & 7160 & 3380 & 4640 & 7400 \\
$\mathbf{2 3}$ & V2w4 & 10 & 118 & 332 & 530 & 2510 & 7560 & 11370 & 5950 & 11150 & 10250 \\
$\mathbf{2 4}$ & V3w4 & 10 & 139 & 289 & 813 & 1700 & 3380 & 10220 & 5860 & 8380 & 10820 \\
$\mathbf{2 5}$ & V4w4 & 10 & 121 & 609 & 753 & 2030 & 2780 & 9070 & 5800 & 19530 & 9100 \\
\hline
\end{tabular}

Berdasarkan Tabel 1 di atas, dapat dilihat bahwa kepadatan rata - rata populasi Chlorella sp. tertinggi dengan perlakuan tanpa pupuk walne, yaitu pada perlakuan V4W4 pada hari ke-9 sebanyak $19.530 \times 10^{4} \mathrm{sel} / \mathrm{ml}$ dengan nilai laju pertumbuhannya (k) sebesar 1,8 sel/hari. Hal ini berarti bahwa populasi Chlorella sp. dapat tumbuh optimal pada penggunaan vermikompos dan walne dengan masing - masing konsentrasi $0,025 \%$ dan $0,02 \%$. Namun, populasi Chlorella sp. menurun drastis pada hari ke-10 dengan kepadatan rata - rata, yaitu $9100 \times 10^{4} \mathrm{sel} / \mathrm{ml}$, pada fase ini telah memasuki fase kematian akibat jumlah nutrien yang semakin terbatas. Perlakuan tertinggi kedua ditunjukkan pada kombinasi perlakuan V2W2 dengan jumlah kepadatan populasi sebanyak $14.260 \times 10^{4} \mathrm{sel} / \mathrm{ml}$ pada hari ke-10 dengan konsentrasi vermikompos $0,015 \%$ dan walne $0,001 \%$. Sedangkan pada perlakuan VOW0 jumlah populasi menunjukkan penurunan sampai hari ke-10 dengan jumlah kepadatan populasi $330 \times 10^{4} \mathrm{sel} / \mathrm{ml}$. Hal ini dapat terjadi karena pada perlakuan VoW0 (kontrol) tidak diberikan nutrien baik pupuk walne maupun vermikompos sehingga sel Chlorella sp. sehingga mengalami kekurangan nutrien yang berdampak pada persaingan dan kematian sel. Perlakuan VOW0 memiliki tingkat kepadatan yang selalu lebih rendah dari perlakuan lainnya.

Pada Tabel di atas semua perlakuan menunjukkan hasil pertumbuhan yang berbeda - beda. Pada hari kedua rata - rata jumlah populasi meningkat sangat cepat yang dapat dilihat dari besarnya nilai laju pertumbuhan $(\mathrm{k})$ pada semua perlakuan dan yang paling tinggi laju pertumbuhannya $(k)$ pada perlakuan V2W0 dengan laju 4,71 sel/hari. Hal ini sesuai pernyataan Sutomo, 2005 dalam Sukesi, dkk (2009), bahwa pada awal pertumbuhan nilai laju pertumbuhan relatif yang tinggi menunjukkan mikroalga cepat memiliki daya adaptasi terhadap lingkungan kultur yang baru dan menunjukkan bahwa alga tersebut mengalami daya adaptasi yang cukup singkat dan langsung tumbuh dengan cepat. Pada pengamatan hari ketiga jumlah kepadatan rata rata populasi mengalami peningkatan populasi tetapi belum terlalu banyak. Hal ini disebabkan karena populasi Chlorella sp. memasuki fase lag (adaptasi) di mana pada fase ini Chlorella sp. menyesuaikan diri dengan kondisi lingkungannya dan kandungan nutrisi yang ada pada medium pertumbuhannya sehingga partumbuhannya sangat lambat. Berdasarkan penelitian yang dilakukan oleh Chlimawanti dan Suminto (2008), menyatakan bahwa perbedaan lamanya masa adaptasi diduga karena adanya perbedaan kepekatan antara media kultur dengan cairan tubuh sel alga, dalam masa 
adaptasi sel - sel memulihkan enzim dan konsentrasi substrat ke tingkat yang diperlukan untuk pertumbuhan serta masukya unsur hara ke dalam sel fitoplankton terjadi melalui proses difusi sebagai akibat perbedaan konsentrasi antara media kultur dengan cairan tubuh. Pada hari ke-4 sampai pada hari ke-6 jumlah kepadatan rata rata populasinya mulai meningkat secara eksponensial (fase eksponensial) di mana pada fase ini pertumbuhan Chlorella sp. sangat cepat, karena sel mengalami pembelahan yang sangat cepat karena kandungan ketersedian nutrien yang mendukung pertumbuhannya. Jumlah populasi tertinggi sampai hari ke-6 mencapai $7560 \times 10^{4} \mathrm{sel} / \mathrm{ml}$, dengan nilai laju pertumbuhan (k) meningkat sebesar $1,54 \mathrm{sel} / \mathrm{hari}$. Hal ini juga dapat dilihat dari perubahan warna medium kultur yang berwarna hijau pekatmenunjukkan tingginya kepadatan sel dalam media kultur. Hasil ini sesuai dengan hasil penelitian yang dilakukan Suminto dan Hirayama (1996), bahwa nilai k yang lebih besar mempunyai arti bahwa proses pembelahan sel alga menjadi lebih cepat, sehingga pertambahan sel per satuan waktu akan lebih besar dari pada pertambahan waktu itu sendiri. Namun demikian terdapat pula perlakuan yang mengalami penurunan populasi, yaitu pada perlakuan V4W2 yang terjadi pada hari ke4 dengan nilai laju pertumbuhan (k) adalah -0.04 sel/hari (tidak ada pertumbuhan tetapi terjadi kematian sel), VOW0 pada hari kelima dengan nilai $k=-0,07$ sel/hari. Pada hari ke-8 sampai pada hari ke-10 jumlah populasi meningkat secara fluktuatif yang berarti ada yang meningkat dan ada yang mengalami penurunan. Hal ini disebabkan karena adanya dinamika populasi, yaitu naik turunnya suatu organisme atau populasi karena adanya faktor intrinsik dan ekstrinsik dari organisme tersebut. Hasil penelitian ini didukung oleh pernyataan Odum (1988) yang menyatakan bahwa kompetisi, sifat fisik lingkungan, predasi, gejala tingkah laku, dan gejala kinetik dipertimbangkan sebagai faktor pengatur populasi. Sedangkan populasi yang terkontrol akan mengalami perubahan tingkat kepadatan, dengan berubahnya daya dukung. Jika daya dukung berubah menurut waktu tahapan fase populasi juga berubah. Faktor - faktor pada populasi Chlorella sp. seperti kelahiran, kematian, penyebaran, bentuk pertumbuhan dan perkembangan, serta sifat genetik akan mempengaruhi kerapatan dan jumlah populasi Chlorella sp. yang dalam waktu berbeda akan mengalami penurunan dan peningkatan populasi.

Kelima grafik yang menunjukkan peningkatan populasi tertinggi berturut-turut, yaitu pada perlakuan V1W0, V2W1, V2W2, V3W3, dan V4W4. Hal ini dapat disebabkan karena nutrien yang terkandung baik unsur makro dan unsur mikro masih sangat banyak yang berasal dari interaksi antara kandungan pupuk organik (vermikompos cair) dan pupuk anorganik (walne).Untuk perlakuan V4W1 diperoleh jumlah populasi yang lebih rendah dibandingkan perlakuan V2W1 dan V3W1. Hal ini menunjukkan bahwa Chlorella sp. hanya dapat tumbuh optimal dengan konsentrasi pupuk yang tidak berlebih sehingga pertumbuhan optimal untuk populasi Chlorella sp., yaitu pada perlakuan V2W1 dan V3W1. Jumlah populasi dari ke-4 perlakuan konsentrasi vermikompos dan walnedapat dilihat mengalami masa puncak beberapa kali kemudian menurun lagi. Hal ini disebabkan jumlah populasi yang semakin padat sehingga keberadaan sel dalam ruang media kultur sangat sempit yang menyebabkan adanya sel yang mengalami kematian namun populasi akan meningkat kembali karena adanya sel yang mengalami kematian sedangkan kebutuhan akan nutrien masih memadai sehingga populasi yang masih bertahan dapat hidup dan bereproduksi. Pengurangan populasi ini disebabkan karena kultur yang dilakukan pada volume yang terbatas yang menyebabkan jumlah nutrien yang terkandung dalam media juga terbatas sehingga Chlorella sp. tidak mampu lagi mempertahankan kepadatan selnya. Kepadatan sel tertinggi yang terjadi pada perlakuan V4W4 juga dapat dilihat dari medium pertumbuhan yang berwarna hijau pekat. Warna hijau pekat ini disebabkan karena adanya unsur Boron yang terkandung baik pada pupuk vermikompos maupun 
pada walne, di mana Boron berfungsi untuk mempertahankan pigmen. Hal ini terbukti dengan lebih hijaunya sel Chlorella sp. yang dikultur pada media ini. Menurut Round (1973), kekurangan Boron dapat menyebabkan sel alga kehilangan pigmen.

Pada perlakuan V4W4 fase kematian atau penurunan diperoleh pada hari ke10 di mana jumlah populasi sebanyak $9.100 \times 10^{4} \mathrm{sel} / \mathrm{ml}$. Pada grafik perlakuan V4W4 terdapat 2 fase puncak, yaitu pada hari ke-7 dan hari ke-10 hal ini dapat terjadi karena faktor suhu yang berubah - ubah sehingga ada populasi yang naik dan turun. Namun, perlakuan V4W4 memiliki pertumbuhan yang sangat optimal untuk populasi Chlorella sp. jika dibandingkan dari keseluruhan perlakuan. Kepadatan sel tertinggi terdapat pada perlakuan V4W4 hari ke-9 di mana konsentrasi pupuk vermikompos yang digunakan sebanyak $0.25 \%$ dan pupuk walne sebanyak $0.002 \%$ dengan jumlah kepadatan populasi sebanyak $19530 \times 10^{4} \mathrm{sel} / \mathrm{ml}$ dengan rata - rata laju pertumbuhan yaitu 1,8/hari. Hal ini disebabkan karena unsur pupuk walne dan pupuk vermikompos mengandung unsur - unsur $\mathrm{Fe}, \mathrm{Mn}, \mathrm{Cl}$, dan $\mathrm{Zn}$ lebih banyak tersedia dari pada media yang lainnya. Unsur - unsur tersebut digunakan Chlorella sp. untuk proses fotosintesis, di mana hasilnya digunakan untuk pertumbuhan (Fogg, 1965). Pada media walne juga mengandung vitamin lengkap yang digunakan sebagai pemacu pertumbuhan terutama vitamin B12, di mana pada perlakuan V4W4 unsur lebih lengkap. Beberapa strain Chlorella sp. mampu menyerap vitamin B12 yang terdapat dalam media kultur lebih banyak dari jenis lain (Yu et al., 1994). Maruyama (1989) dalam Yu et al. (1994) bahwa vitamin B12 pada strain Chlorella sp. tidak kurang dari 0,26 $\mu \mathrm{g} / 100 \mathrm{~g}$ kering. Selain itu media ini mempunyai unsur Si yang digunakan dalam pembentukan dinding sel selain untuk pemacu pertumbuhan. Dari hasil uji kandungan vermikompos cair yang dilakukan di Laboratorium IImu Tanah Fakultas Peternakan UNHAS diperoleh kandungan unsur makro berupa Nitrogen $(N)$ sebanyak 0,59\%, Posfor $(P)$ 0,52\%, dan Kalsium (K) sebanyak $0,49 \%$. Hal ini berarti bahwa kandungan yang terdapat pada vermikompos cair cukup memadai bagi Chlorella sp. untuk dapat tumbuh secara optimal.

Berdasarkan penelitian yang dilakukan oleh Menon dan Pillai (2000) di India bahwa walaupun banyak mikroalga yang dapat tumbuh pada media anorganik murni tetapi beberapa dari mikroalga lebih menyukai komponen organik sebagai komponen pengganti pupuk yang sebenarnya. Meskipun media Schrelbeirs dan Miquel's telah ditemukan sangat efektif untuk kultur beberapa fitoplankton namun beberapa media organik mengandung trace metals, vitamin, dan beberapa garam - garam organik dan anorganik. Data kepadatan populasi Chlorella sp. yang diperoleh didukung juga oleh faktor fisika, kimia, dan biologi. Suhu yang digunakan untuk pertumbuhan populasi Chlorella sp. pada penelitian ini yaitu antara $19^{\circ}-25^{\circ} \mathrm{C}$ di mana suhu ini sangat optimal bagi pertumbuhan Chlorella sp. Suhu mempengaruhi suatu stadium daur hidup organisme dan merupakan faktor pembatas penyebaran suatu spesies. Dalam mempertahankan keberlangsungan hidup dan reproduksi secara ekologis perubahan suhu menyebabkan perbedaan komposisi dan kelimpahan Chlorella sp.. Sedangkan menurut Dwidjoseputro (1986) suhu $25^{\circ}-32^{0} \mathrm{C}$ pertumbuhan Chlorella sp. terjadi secara normal. Salinitas merupakan salah satu faktor lingkungan yang dapat mempengaruhi tekanan osmotik antara protoplasma sel organisme dengan lingkungannya. Kadar garam yang berubah-ubah dalam air dapat menimbulkan hambatan bagi kultur Chlorella sp.. Pada penelitian ini salinitas yang digunakan, yaitu 30 ppt di mana salinitas ini merupakan kadar yang sangat baik untuk pertumbuhan Chlorella sp.. Dalam penelitian ini pH (derajat keasaman) yang diukur, yaitu 7 yang berarti bahwa Chlorella sp. dapat tumbuh optimal dalam medium pertumbuhannya. Menurut Knutzen, (1981), derajat keasaman (pH) merupakan salah satu faktor yang berpengaruh secara langsung terhadap pertumbuhan populasi sel Chlorella sp..pH air media berperan dalam membentuk konsentrasi oksigen dan keseimbangan antara 
bikarbonat dan karbonat. Chlorella sp. berfotosintesis pada kisaran $\mathrm{pH} 7$ - 8. Menurut Yunus (1992), pada kisaran pH 7,88 - 8,47 Chlorella sp. masih dapat tumbuh dengan baik. Umumnya Chlorella sp. dapat tumbuh baik pada kisaran $\mathrm{pH}$ optimum antara 8,0 8,5 (Dwidjoseputro, 1986). Hasil pengukuran $\mathrm{pH}$ dalam penelitian ini juga didukung oleh penelitian yang dilakukan oleh Dominic, dkk pada tahun 2009, yaitu pH yang digunakan untuk pertumbuhan Chlorella sp. berkisar antara 6 - 8 di mana kondisi pH tersebut Chlorella sp. dapat tumbuh optimal.

Karbondioksida merupakan gas terpenting untuk proses fotosintesis. Proses pembudidayaan Chlorella sp. sangat diperlukan adanya aerasi yang berguna agar tidak terjadi pengendapan dan membantu proses fotosintesis. Hal tersebut juga dijelaskan oleh Daniello (2005) tentang keberadaan karbondioksida dan sinar matahari yang cukup sangat mendukung pertumbuhan alga. Organisme fotosintesis mikroskopik ini dapat tumbuh cepat, sehingga memungkinkan dapat dipanen dalam beberapa hari, hal inilah yang stidak dapat dilakukan pada sayuran atau gandum. Martosudarmo dan Wulani (1990) cit Wahyuna (2002) menyatakan bahwa pertumbuhan Chlorella sp. sangat tergantung pada intensitas lamanya penyinaran dan panjang gelombang cahaya yang mengenai sel-sel tanaman selama fotosintesis. Umumnya dalam ruang kultur intensitas cahaya berkisar antara 500 - 5000 lux. Keadaan gelap dan terang juga harus dikontrol. Kultur penyediaan bibit, intensitas cahaya yang diberikan berkisar antara 500 - 1000 lux, biasanya 12 jam dalam keadaan terang dan 12 jam dalam keadaaan gelap. Dalam penelitian ini rata - rata intensitas cahaya yang digunakan, yaitu 3200 lux sehingga populasi dapat tumbuh optimal. Nilai intensitas yang digunakan dalam penelitian ini sesuai dengan kisaran intensitas cahaya yang digunakan oleh Oh-Hama dan Miyachi (1992), yaitu antara 3000 - 30000 lux.

\section{KESIMPULAN}

Kesimpulan dari penelitian ini adalah kombinasi perlakuan media kultur antara pupuk vermikompos cair dan pupuk walne tidak memperlihatkan pengaruh nyata antar perlakuan yang diberikan terhadap pertumbuhan populasi sel Chlorella sp.. Kombinasi perlakuan yang memberikan pertumbuhan populasi sel Chlorella sp. tertinggi adalah V4W4 (konsentrasi $0,025 \%$ vermikompos dan 0,002\% walne) dengan rata - rata kepadatan populasi sebanyak $19.53010^{4} \mathrm{sel} / \mathrm{ml}$, yang terjadi pada hari ke-10.

\section{DAFTAR PUSTAKA}

Bambang Prijamboedi, Veinardi Suendo, Enny Ratnaningsih, Lily Maria Goretty Panggabean, Santi Nurbaiti . 2015.Tropical marine Chlorella sp. PP1 as a source of photosynthetic pigments for dye-sensitized solar cells.Algal Research 10: 25 32

Chilmawati, D., dan Suminto., 2008. Penggunaan Media Kultur yang Berbeda terhadap Pertumbuhan Chlorella sp. Budidaya Perairan. Jurusan Perikanan Fakultas Perikanan dan Ilmu Kelautan Universitas Diponegoro. Semarang.

Daniello, Olivier. 2005. An Algae Based Fuel. Biofutur N0. 255 ditebitkan Mei 2005

Dominic V.J, S. Murali, dan Nisha M.C., 2009. Phycoremediation Efficiency of Micro Algae Chlorella vulgaris, Synechocystis salina, and Gloeocapsa gelatinosa. Department of Botany, Centre for PG studies and Research, Sacred Heart College, Thevara, Ernakulam (Dt.). Kerala.

Dwijoseputro, 1980. Pengantar Fisiologi Tumbuhan. Penerbit Gramedia . Jakarta.

Hui Chena, Jie Wang, Yanli Zhenga, Jiao Zhana, Chenliu Hea, Qiang Wang. 2018. Algal biofuel production coupled bioremediation of biomass power plant wastes based on Chlorella sp. C2 cultivation. Applied Energy 211: 296-305. 
Maharsari, A.P., 2011. Pengaruh Pemberian Campuran Pupuk Limbah Padi- Azolla sp. Urea terhadap Laju Pertumbuhan Chlorella sp. http://digilib.unesa.org/ index.php?com=digilib\&view=list \& item id=Journal. Diakses pada tanggal 5 Maret 2012.

N. Mohammady , S.I. Hawash , K.M. El-Khatib , M.I. El-Galad, G. El Diwani. 2015. Biodiesel production from Chlorella $s p$ : Process Design and Preliminary Economic Evaluation. International Journal of ChemTech Research Vol.8, No.9, pp 297-304

Prihantini, N.B., Berta Putri, dan Ratna Yuniati, 2005. Pertumbuhan Chlorella sp. dalam Medium Ekstrak Tauge (MET) dengan Variasi pH Awal. Departemen Biologi, Fakultas MIPA. Universitas Indonesia. Indonesia

Prihatman, 2000. Budidaya Cacing Tanah (Lumbricus sp.). Proyek Pengembangan Ekonomi Masyarakat Pedesaan. Bappenas

Priyadi, A., Chumaidi, G. Dharma, 1990. Pengaruh Kadar Urea terhadap Pertumbuhan Populasi Chlorella sp.. Bulletin Penelitian Perikanan Darat. volume 9 no.1.

Rifai, R., 1994. Kandungan Protein Mikroalgae Chlorella sp. pada Media kultur yang Berbeda. Skripsi. Fakultas IImu Kelautan dan Perikanan. Universitas Hasanuddin. Makassar.

Surhayanto. 2001. Vermikompos. Jurusan Peternakan Fakultas Pertanian. Universitas Bengkulu.

Wirosaputro, S., 1998. Chlorella Makanan Kesehatan Global Alami. Gadjah Mada University Press. Yogyakarta.

Zeily Nurachman, Hartini H, Wiwit Ridhani Rahmaniyah, Dewi Kurnia, Rahmat Hidayat 